\title{
US ventilator crisis brings patients and doctors face-to-face with life-or-death choices
}

The possibility of running out of ventilators for patients with covid-19 has ramped up the debate in the US on how to ration care, Kim Painter reports

\author{
Kim Painter freelance journalist
}

McLean, Virginia, USA

Ivanova Smith, a 31 year old woman who lives in Tacoma, Washington, says she "would be terrified" if she had to be hospitalised for covid-19. One reason is that she would be alone in the hospital, without visitors. And now Smith, who has an intellectual disability and autism, has other reasons to be afraid. She recently learnt of guidelines circulated by Washington state health officials that she feared would send people with disabilities to their deaths if ventilators run short.

A section, now removed, from those rationing guidelines ${ }^{1}$ gave a low priority to people with "loss of reserves in energy, physical ability, cognition, and general health," according to a complaint Smith and other advocates for people with disabilities filed with US Department of Health and Human Services (HHS) Office for Civil Rights. ${ }^{2}$ That language violated the principle that "all people are people, regardless of their support needs," Smith says.

The Washington state guidelines are among many rationing schemes that have drawn fire in the weeks since the covid-19 crisis raised the prospect of ventilator shortages in the US. Ventilator rationing has not, so far, been reported-and the immediate danger may have passed-but the possibility has ignited widespread concerns.

In Alabama, language on state websites since 2010 would have denied breathing machines to anyone with "severe or profound mental retardation" or "moderate to severe dementia," according to a now resolved federal civil rights complaint. ${ }^{3}$ The complaint said the plan was "a clear violation of disability discrimination laws." The language was removed after the complaint was filed.

In Massachusetts and Pennsylvania, guidelines unveiled just weeks ago have already been revised after advocates for racial minorities, disabled people, and older citizens raised objections about the low priority given to people with some pre-existing conditions. ${ }^{45}$ Such triage plans reinforce discrimination against already marginalised groups, advocates say.

Meanwhile, in New York, the state hardest hit by covid-19, government leaders have yet to endorse or update a 272 page ventilator rationing guideline ${ }^{6}$ completed by an advisory committee in 2015 , after years of debate and public comment. That triage plan rejects considerations of old age or long term survival, but it's not clear if hospitals are prepared to use it. There is "no protocol" for rationing, governor Andrew Cuomo said at a press conference in late March.?

\section{A state by state matter}

A scenario long envisioned by medical ethicists was, until now, "just an abstraction to most people," says Dan Hanfling, an emergency physician at Inova Fairfax Hospital in Virginia. He co-chaired a committee that, over the past decade, wrote broad recommendations on "crisis standards of care" for the US Institute of Medicine (now the National Academy of Medicine), a private, non-profit group frequently called on by the federal government for advice. ${ }^{8}$

Those broad guidelines, which call for fairness, transparency, and saving as many lives as possible, do not spell out exactly how scarce resources, such as ventilators, should be rationed. So, while many states have used the academy guidelines as a starting point, details of their plans vary. Some individual hospitals and hospital systems also have their own plans, with their own variations. Other states and institutions have yet to make any plans public.

Some of the state and hospital plans that have been released exclude people with a short life expectancy from ventilator consideration, even if they might survive the immediate illness. Others give people nearing death a low priority score, but don't exclude them. Some plans use age or life stage to set priorities among people in otherwise similar health. Some give children extra priority. And some plans give extra consideration to health workers, because they might help others survive.

Variation, even if it means a person might get a ventilator in one place but not another, is not necessarily a bad thing, some experts say.

"Californians may be quite different from Alabamans" in their values, says Douglas White, an intensive care physician who directs a University of Pittsburgh programme on ethics in critical medicine. 
But, White says, that doesn't mean it's okay to discriminate on the basis of disability or health differences driven by racial or socioeconomic inequality.

For the most part, states and healthcare providers are making an urgent effort to find the right balance, White says. He's the co-author of a detailed set of model guidelines that many hospitals and states, including Pennsylvania, have used to develop their plans. A version he and his colleagues published in JAMA in late March listed examples of conditions that might reduce life expectancy and put patients lower on the priority list. $^{9}$

After concerns were raised about how such lists might lead to blanket judgments about already vulnerable groups, White and his colleagues posted a revised version that removes the examples and says anyone with a life expectancy beyond five years should get equal consideration. ${ }^{10}$ Those with less than one year to live get lower priority. Age groups are used as tie breakers.

\section{Justice and fairness}

The fact that many ventilator rationing policies are now undergoing public scrutiny - and that some are being revised as a result-is "probably a good thing," says Valerie Gutmann Koch, director of law and ethics at the University of Chicago's MacLean Center for Clinical Medical Ethics. She served as a staff attorney and advisor on the 2015 New York guidelines.

She says finding policies the public can accept, even if they are never used, is crucial for protecting faith in the healthcare system. The covid-19 ventilator debate forces Americans to grapple with challenging problems, she says. "It's difficult for us as a country to wrap our heads around the idea that this isn't about individual decision making anymore. We have to focus on the principles of justice and fairness in the way we don't always do."

In March, the HHS Office for Civil Rights put out a bulletin reminding states and healthcare providers that federal laws prohibiting discrimination based on disability, age, race, and other factors remain in effect, even in a crisis. ${ }^{11}$

"It was a strong message to states coming from the federal government that discrimination is not going to be tolerated," says Shira Wakschlag, director of legal advocacy at The Arc, a group representing people with intellectual and developmental disabilities. She says her group and others are working with states to modify disputed policies.

As of late April, disability rights advocates had filed federal civil rights complaints about ventilator rationing plans in at least six states, including Alabama, Oklahoma, Pennsylvania, Tennessee, Utah, and Washington. ${ }^{11}$ Two of those complaints, against Alabama and Pennsylvania, have been resolved after policies were rescinded or revised. ${ }^{12}$

In Washington state, where Ivanova Smith lives, the Department of Health is committed to "equal access to treatment under the law for people with disabilities," public information officer Becky Bennett said in an email.

In general, disability rights groups accept that patients most likely to survive the immediate crisis will get top priority when resources are scarce, Wakschlag says. But when decision makers look at longer term survival, the danger of bias against disabled people is high, she says.

Still, many medical ethicists argue that looking at only immediate survival creates other kinds of unfairness. "No one should deny anyone with a disability a seat on the lifeboat," says Arthur Caplan, director of medical ethics at New York University Langone Medical Center. But when resources are scarce, it is fair to consider life expectancy, he says. A healthy person with Down Syndrome might well get higher priority than someone with an end stage disease or multiple chronic illnesses.

All the experts and advocates agree that none of the choices are good.

"Any day we can avoid having to do something like this in the US," Hanfling says, "is a day we can be thankful for."

1 Washington State Department of Health, Northwest Healthcare Response Network. Scarce resource management and crisis standards of care. 2020. https://nwhrn.org/wp-content/ uploads/2020/03/Scarce_Resource_Management_and_Crisis_Standards_of_Care_ Overview_and_Materials-2020-3-16.pdf.

2 Disability Rights Washington. Washington complaint. 23 March 2020. http://thearc.org/ wp-content/uploads/2020/03/OCR-Complaint_3-23-20.pdf.

3 Alabama Disabilities Advocacy Program. Alabama complaint. 24 March 2020. http://thearc. org/wp-content/uploads/2020/03/AL-OCR-Complaint_3.24.20.docx.pdf.

4 Disability Rights Pennsylvania. Pennsylvania complaint. 2020. www.centerforpublicrep. org/wp-content/uploads/2020/04/04.03.2020-DRP-OCR-Complaint-with-Exhibit-A-1.pdf.

5 After uproar, Mass. revises guidelines on who gets an ICU bed or ventilator amid covid-19 surge. WBUR. 20 April 2020. www.wbur.org/commonhealth/2020/04/20/mass-guidelinesventilator-covid-coronavirus.

6 New York State Task Force on Life and the Law, New York State Department of Health. Ventilator allocation guidelines. November 2015. www.health.ny.gov/regulations/task_ force/reports_publications/docs/ventilator_guidelines.pdf.

7 Ventilator shortages loom as states ponder rules for rationing. NPR. 3 April 2020. www. npr.org/sections/health-shots/2020/04/03/826082727/ventilator-shortages-loom-as-statesponder-rules-for-rationing

8 National Academies of Science, Engineering, and Medicine. Rapid expert consultation on crisis standards of care for the covid-19 pandemic. 28 March 2020. www.nap.edu/ catalog/25765/rapid-expert-consultation-on-crisis-standards-of-care-for-the-covid-19pandemic-march-28-2020.

9 White DB, Lo B. A framework for rationing ventilators and critical care beds during the covid-19 pandemic. JAMA 2020. 10.1001/jama.2020.5046. 32219367

10 University of Pittsburgh. Allocation of scarce critical care resources during a public health emergency. 15 April 2020. https://ccm.pitt.edu/sites/default/files/UnivPittsburgh_ ModelHospitalResourcePolicy_2020_04_15.pdf.

11 HHS-OCR complaints re covid-19 treatment rationing. The Arc. 23 March 2020. https:// thearc.org/resource/hhs-ocr-complaint-of-disability-rights-washington-self-advocates-inleadership-the-arc-of-the-united-states-and-ivanova-smith

12 US Department of Health and Human Services. HIPAA and covid-19. www.hhs.gov/hipaa/ for-professionals/special-topics/hipaa-covid19/index.html.

Published by the BMJ Publishing Group Limited. For permission to use (where not already granted under a licence) please go to http://group.bmj.com/group/rights-licensing/ permissions 